\title{
Front Matter: Volume 10642
}

, "Front Matter: Volume 10642," Proc. SPIE 10642, Degraded Environments: Sensing, Processing, and Display 2018, 1064201 (16 July 2018); doi: $10.1117 / 12.2501420$

SPIE. Event: SPIE Defense + Security, 2018, Orlando, FL, United States 


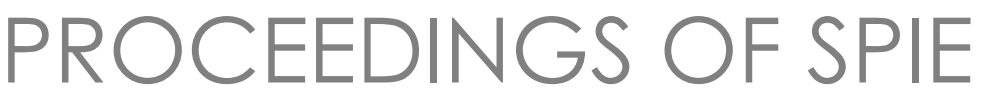

\section{Degraded Environments: Sensing, Processing, and Display 2018}

John (Jack) N. Sanders-Reed

Jarvis (Trey) J. Arthur III

Editors

17-18 April 2018

Orlando, Florida, United States

Sponsored and Published by

SPIE 
The papers in this volume were part of the technical conference cited on the cover and title page. Papers were selected and subject to review by the editors and conference program committee. Some conference presentations may not be available for publication. Additional papers and presentation recordings may be available online in the SPIE Digital Library at SPIEDigitallibrary.org.

The papers reflect the work and thoughts of the authors and are published herein as submitted. The publisher is not responsible for the validity of the information or for any outcomes resulting from reliance thereon.

Please use the following format to cite material from these proceedings:

Author(s), "Title of Paper," in Degraded Environments: Sensing, Processing, and Display 2018, edited by John (Jack) N. Sanders-Reed, Jarvis (Trey) J. Arthur III, Proceedings of SPIE Vol. 10642 (SPIE, Bellingham, WA, 2018) Seven-digit Article CID Number.

ISSN: 0277-786X

ISSN: 1996-756X (electronic)

ISBN: 9781510617957

ISBN: 9781510617964 (electronic)

Published by

SPIE

P.O. Box 10, Bellingham, Washington 98227-0010 USA

Telephone +1 3606763290 (Pacific Time) · Fax +1 3606471445

SPIE.org

Copyright (C) 2018, Society of Photo-Optical Instrumentation Engineers.

Copying of material in this book for internal or personal use, or for the internal or personal use of specific clients, beyond the fair use provisions granted by the U.S. Copyright Law is authorized by SPIE subject to payment of copying fees. The Transactional Reporting Service base fee for this volume is $\$ 18.00$ per article (or portion thereof), which should be paid directly to the Copyright Clearance Center (CCC), 222 Rosewood Drive, Danvers, MA 01923. Payment may also be made electronically through CCC Online at copyright.com. Other copying for republication, resale, advertising or promotion, or any form of systematic or multiple reproduction of any material in this book is prohibited except with permission in writing from the publisher. The CCC fee code is 0277$786 \mathrm{X} / 18 / \$ 18.00$.

Printed in the United States of America.

Publication of record for individual papers is online in the SPIE Digital Library.

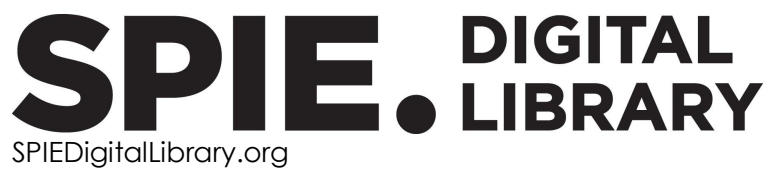

Paper Numbering: Proceedings of SPIE follow an e-First publication model. A unique citation identifier (CID) number is assigned to each article at the time of publication. Utilization of CIDs allows articles to be fully citable as soon as they are published online, and connects the same identifier to all online and print versions of the publication. SPIE uses a seven-digit CID article numbering system structured as follows:

- The first five digits correspond to the SPIE volume number.

- The last two digits indicate publication order within the volume using a Base 36 numbering system employing both numerals and letters. These two-number sets start with $00,01,02,03,04$, $05,06,07,08,09,0 A, 0 B \ldots$. OZ, followed by 10-1Z, 20-2Z, etc. The CID Number appears on each page of the manuscript. 


\title{
Contents
}

\author{
vii Authors \\ ix Conference Committee
}

\section{SESSION 1 DISPLAYS AND HUMAN PERFORMANCE I}

1064202 Determination of $\mathbf{2 5 5}$ just noticeable color gray level differences for improved color palette [10642-1]

1064203 HMD daylight symbology: color discrimination modeling [10642-2]

1064204 Modeling the effect of macular pigment enhancement on vision in degraded visual environments (DVE) [10642-3]

1064205 Review of sensor-to-eye latency effects in degraded visual environment mitigations [10642-4]

1064206 Color and impact to HMD design [10642-5]

$1064207 \quad$ Predicting depth discrimination performance under hyperstereoscopic display conditions [10642-6]

\section{SESSION 2 DISPLAYS AND HUMAN PERFORMANCE II}

1064209 Visibility of color symbology in head-up and head-mounted displays in daylight environments [10642-8]

\section{SESSION $3 \quad$ SYSTEMS AND PROCESSING I}

$106420 \mathrm{~A} \quad 360$-degree top view inside a helmet mounted display providing obstacle awareness for helicopter operations [10642-9]

$10642 \mathrm{OB}$ Synthetic vision on a head-worn display supporting helicopter offshore operations [10642-10]

$106420 \mathrm{C}$ Real-time sonic boom prediction with flight guidance [10642-12]

10642 OD Evaluating synthetic vision displays for enhanced airplane state awareness [10642-13] 
10642 OF Passive EO imaging sensor assessment methodology [10642-15]

10642 OG Advanced low-SWAP lidar imager for degraded visual environments [10642-16]

10642 Ol NIAG DVE flight test results of LiDAR based DVE support systems [10642-18]

SESSION 5 SYSTEMS AND PROCESSING II

$106420 \mathrm{~J} \quad$ Integrating legacy ESVS displays in the Unity game engine [10642-20]

10642 OL Rotorcraft pinnacle landing situational awareness system [10642-23]

SESSION 6 DISPLAYS AND HUMAN PERFORMANCE III

10642 OM Feeling a little blue: problems with the symbol color blue for see-through displays and an alternative color solution [10642-24]

10642 ON DEVS: providing dismounted 24/7 DVE capability and enabling the digital battlefield [10642-25]

SESSION 7 GPS DENIED ENVIRONMENTS

$1064200 \quad$ Relative visual localization (RVL) for UAV navigation [10642-28]

10642 OP Location and head orientation tracking in GPS-denied environments [10642-26]

SESSION 8 MMW AND DVE PHENOMENOLOGY AND SENSING: JOINT SESSION WITH CONFERENCES 10642 AND 10634

$106420 Q \quad$ Visualization requirements for DVE systems [10642-29]

10642 OR DVE system capability classes [10642-30]

10642 OS Visibility in degraded visual environments (DVE) [10642-31]

10642 OU High fill factor RF aperture arrays for improved passive, real-time millimeter wave imaging [10642-33]

iv 
POSTER SESSION

10642 OV Improving AVHRR-based NDVI data using a statistical technique for global climate studies [10642-19]

Proc. of SPIE Vol. 10642 1064201-5

Downloaded From: https://www.spiedigitallibrary.org/conference-proceedings-of-spie on 26 Apr 2023 Terms of Use: https://www.spiedigitallibrary.org/terms-of-use 
Proc. of SPIE Vol. 10642 1064201-6

Downloaded From: https://www.spiedigitallibrary.org/conference-proceedings-of-spie on 26 Apr 2023 Terms of Use: https://www.spiedigitallibrary.org/terms-of-use 


\section{Authors}

Numbers in the index correspond to the last two digits of the seven-digit citation identifier (CID) article numbering system used in Proceedings of SPIE. The first five digits reflect the volume number. Base 36 numbering is employed for the last two digits and indicates the order of articles within the volume. Numbers start with 00, 01, 02, 03, 04, 05, 06, 07, 08, 09, 0A, 0B...0Z, followed by 10-1Z, 20-2Z, etc.

Akhloufi, Moulay A., 00

Allen, Robert C., OL

Arthur, Trey J., OD

Ballard, Kathryn, OD

Blanton, W. Brendan, OL

Browne, Michael P., 09, 0M

Bullock, Tommy, 07

Byrd, James C., 02

Couturier, Andy, 00

Cross, Jack, OQ, OR

Desjardins, Daniel D., 02

Dibernardi, Deanna, OL

Dillon, Thomas E., OU

Doehler, H.-U., OA

Eason, Paul, OG

Ebrecht, Lars, OA, OB

Ellis, Kyle E., OD

Erdmann, Stefan, OB

Ernst, Johannes M., OA, OB, OJ

Fenley, Stephen J., OS

Foote, Bob, 06

Gardner, Patrick, 02

Gestwa, Martin, Ol

Gresko, Katherine, OL

Harding, Thomas $\mathrm{H}$., $\mathrm{O} 3$

Harrity, Charles, OU

Hoffmann, Mitchell, 06

Hovis, Jeffery K., 03

Jones, R. L., OF

Kadik, Abdel Hamid, OV

Kiggins, Daniel K., OD

Kocazik, Stephen, OU

Lake, Renee C., OD

Lattimore, Morris R., 03

Lieberman, Eric, OL

Lloyd, Charles J., 07

Mackrides, Daniel G., OU

Melzer, James E., OP

Moffitt, Kirk, 09, 0M

Morde, Ashutosh, OP

Münsterer, Thomas, 05, 01

Murray, James T., OG

Nicholas, Stephanie N., OD

O'Brien, Kevin, 04

O'Keefe, Eleanor, 07

Passey, G., OF

Peinecke, Niklas, 0J

Plath, Jeffrey, OG

Prather, Dennis W., OU
Prinzel, Lawrence J., III, OD

Rahman, Md. Z., OV

Rash, Clarence E., 03

Rosy, Dilara A., OV

Roytman, Leonid, OV

Ryder, Bill, OG

Sanders-Reed, John N., OS

Schmerwitz, S., OA

Schnell, Thomas, 05

Schuetz, Christopher A., OU

Seely, Jason, OG

Shi, Shouyuan, OU

Shreve, Kevin, OU

Singer, Bernhard, 0

Smith-Velazquez, Laura M., OC

Smolek, Michael K., 03

St. Onge, Paul, 04

Straub, Joseph, ON

Temme, Leonard A., 04

Theunissen, Erik, OC

Van Lieu, Neil, OG

Winterbottom, Marc, 07

Wright, Andrew, OU

Yao, Peng, OU

Zimmermann, Michael, 0 
Proc. of SPIE Vol. 10642 1064201-8

Downloaded From: https://www.spiedigitallibrary.org/conference-proceedings-of-spie on 26 Apr 2023 Terms of Use: https://www.spiedigitallibrary.org/terms-of-use 


\section{Conference Committee}

Symposium Chair

Arthur A. Morrish, Raytheon Space and Airborne Systems

(United States)

Symposium Co-chair

Ruth Moser, Air Force Research Laboratory (United States)

Conference Chairs

John (Jack) N. Sanders-Reed, The Boeing Company (United States)

Jarvis (Trey) J. Arthur III, NASA Langley Research Center (United States)

Conference Program Committee

Brendan W. Blanton, The Boeing Company (United States)

Michael P. Browne, SA Photonics (United States)

Daniel D. Desjardins, Consultant (United States)

Gary W. Jones, NanoQuantum Sciences, Inc. (United States)

Shanalyn A. Kemme, Sandia National Laboratories (United States)

Jim E. Melzer, Thales Visionix, Inc. (United States)

Thomas R. Muensterer, HENSOLDT Sensors GmbH (Germany)

Niklas Peinecke, Deutsches Zentrum für Luft- und Raumfahrt e.V. (Germany)

Kalluri R. Sarma, Honeywell Technology (United States)

Carlo L. Tiana, Rockwell Collins, Inc. (United States)

\section{Session Chairs}

1 Displays and Human Performance I

Michael P. Browne, SA Photonics, Inc. (United States)

Jim E. Melzer, Thales Visionix, Inc. (United States)

2 Displays and Human Performance II

John (Jack) N. Sanders-Reed, The Boeing Company (United States)

3 Systems and Processing I

Niklas Peinecke, Deutsches Zentrum für Luft- und Raumfahrt e.V. (Germany)

Daniel D. Desjardins, Consultant (United States) 
$4 \quad$ Phenomenology and Sensing

Gary W. Jones, NanoQuantum Sciences, Inc. (United States)

John (Jack) N. Sanders-Reed, The Boeing Company (United States)

5 Systems and Processing II

Thomas R. Muensterer, HENSOLDT Sensors GmbH (Germany)

6 Displays and Human Performance III

Niklas Peinecke, Deutsches Zentrum für Luft- und Raumfahrt e.V. (Germany)

7 GPS Denied Environments

Brendan W. Blanton, The Boeing Company (United States)

8 MMW and DVE Phenomenology and Sensing: Joint Session with Conferences 10642 and 10634

Jarvis (Trey) J. Arthur III, NASA Langley Research Center (United States)

David A. Wikner, U.S. Army Research Laboratory (United States) 